\title{
Intrasellar chordomas mimicking pituitary adenoma
}

\author{
Report of three cases
}

\author{
Eleni Thodou, M.D., George Kontogeorgos, M.D., Bernd W. Scheithauer, M.D., \\ Ioanna LekKa, M.D., Spyros Tzanis, M.D., Panagiotis Mariatos, M.D., \\ AND EDWARD R LAWS, JR., M.D. \\ Departments of Pathology and Neurosurgery, General Hospital of Athens, Athens, Greece; \\ Departments of Pathology and Neurosurgery, Metaxa's Central Hospital, Piraeus Greece; \\ Departments of Laboratory Medicine and Pathology, Mayo Clinic, Rochester, Minnesota; and \\ Department of Neurosurgery, University of Virginia, Charlottesville, Virginia
}

\begin{abstract}
Whereas chordomas involving the sellar region are uncommon, largely or entirely intrasellar chordomas are rare. The authors report three cases in which the chordomas filled the pituitary fossa and presented as nonfunctioning pituitary adenomas. All lesions exhibited the typical histological patterns and immunophenotype of chordoma. One tumor, studied ultrastructurally and subjected to DNA analysis, was shown to have a diploid histogram. The authors present a clinicopathological study of these three cases and review the literature on intrasellar chordomas.
\end{abstract}

\author{
KEY WORDS • chordoma • electron microscopy • DNA ploidy • \\ immunohistochemistry $\bullet$ pituitary $\bullet$ sella turcica
}

Chordomas are rare, slow-growing malignant tumors of the midline, representing approximately $1 \%$ of all malignant tumors of the bone and 0.1 to $0.2 \%$ of intracranial neoplasms. ${ }^{10,20}$ They are thought to arise from cell rests, particularly of the proximal and distal extremes of the notochord. Approximately 50\% develop in the sacrococcygeal region, $35 \%$ in the sphenooccipital region, and $15 \%$ in vertebrae. ${ }^{48}$ Most chordomas involving the sellar region are parasellar or suprasellar, and largely or entirely intrasellar lesions are very rare. ${ }^{31,38}$ In terms of their characteristics demonstrated on neuroimaging studies and their clinical presentation, intrasellar chordomas may mimic pituitary adenomas. ${ }^{43}$

In this report we describe the clinical and operative features of three examples of intrasellar chordomas mimicking nonfunctioning pituitary adenoma. All lesions were subjected to immunocytochemistry and one to electron microscopy and DNA image analysis.

\section{MORPHOLOGICAL METHODS}

For light microscopic examination, 4 to $6-\mu \mathrm{m}$ formalin-fixed, paraffin-embedded tissue samples were stained

Abbreviations used in this paper: CEA = carcinoembryonic antigen; CT = computerized tomography; EMA = epithelial membrane antigen; HMW = high-molecular weight; LMW = low-molecular weight MR = magnetic resonance; NSE = neuron-specified enolase; $\alpha 1$-FP $=\alpha 1$-fetroprotein. with hematoxylin and eosin and by the periodic acidSchiff method. For immunocytochemical analysis, the avidin-biotin-peroxidase complex technique was used. Primary antisera were directed against EMA, S-100 protein $\alpha 1$-FP CEA, NSE, vimentin, pan-keratin cocktail, HMW cytokeratins $1,5,10$, and 14, cytokeratins 5 and 8 , and LMW cytokeratins 8,18 , and 19 . Sections were incubated overnight with primary antibodies at $4^{\circ} \mathrm{C}$. Before the application of cytokeratin antibodies, sections were treated with $0.25 \%$ pronase at $37^{\circ} \mathrm{C}$ for 10 minutes. For examination by electron microscopy, 1-mm tissue fragments were fixed in $2.5 \%$ glutaraldehyde, postfixed in osmium tetroxide, routinely processed, and embedded in a Epon-Araldite mixture. Ultrathin sections stained with uranyl acetate and lead citrate were studied using an electron microscope. To determine DNA content, fresh touch preparations fixed in $4 \%$ buffered formaldehyde were stained using the standard Feulgen method. A total of 512 nuclei were examined using the CAS 200 image analyzer.

\section{CASE REPORTS}

\section{Case 1}

This 61-year-old man presented with complaints of retroorbital headache, diplopia, and progressive loss of vision, which was more severe in the left eye, over the past 3 months. Visual field examination disclosed bitemporal hemianopsia. Radiography of the skull revealed enlarge- 


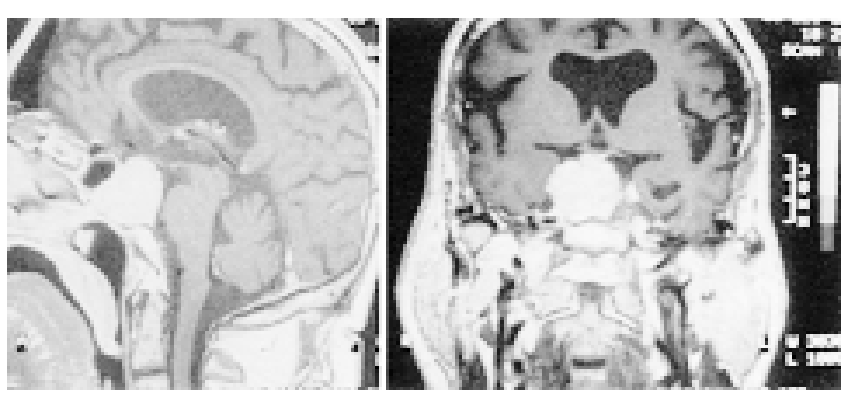

Fig. 1. Case 1. Sagittal (left) and coronal (right) MR images revealing a large, intrasellar tumor elevating and stretching the optic chiasm. Note infiltration of the left cavernous sinus and protrusion of tumor into the sphenoid sinus.

ment and distortion of the sella, with osteolysis of its floor and invasion of the sphenoid bone. A high-resolution CT scan revealed a large, partly calcified intrasellar tumor showing suprasellar extension and erosion of the sphenoid bone. An MR imaging study demonstrated that the lesion measured $3.6 \mathrm{~cm}$ in its greatest diameter and that it elevated and stretched the optic chiasm, infiltrated the left cavernous sinus, and protruded into the sphenoid sinus (Fig. 1). No endocrinopathy was noted, and serum pituitary hormone levels were normal. Initially, the lesion was considered to be a nonfunctioning pituitary adenoma (Grade IVB according to the Hardy classification ${ }^{16}$ ). During transsphenoidal surgery, intrasellar and suprasellar portions of the tumor were resected, the optic chiasm was decompressed, and the intracavernous part of the lesion was subtotally removed. A small portion of the tumor remained attached to the left carotid artery. The patient underwent conventional fractionated radiotherapy, receiving a total dose of 6000 cGy. At 4-year follow-up examination he was asymptomatic.

Pathological Findings. The multiple tan-to-red tumor fragments were composed of large epithelioid and physaliphorous cells arranged in lobules and embedded in a mucoid stroma. The nuclei were round and uniform with

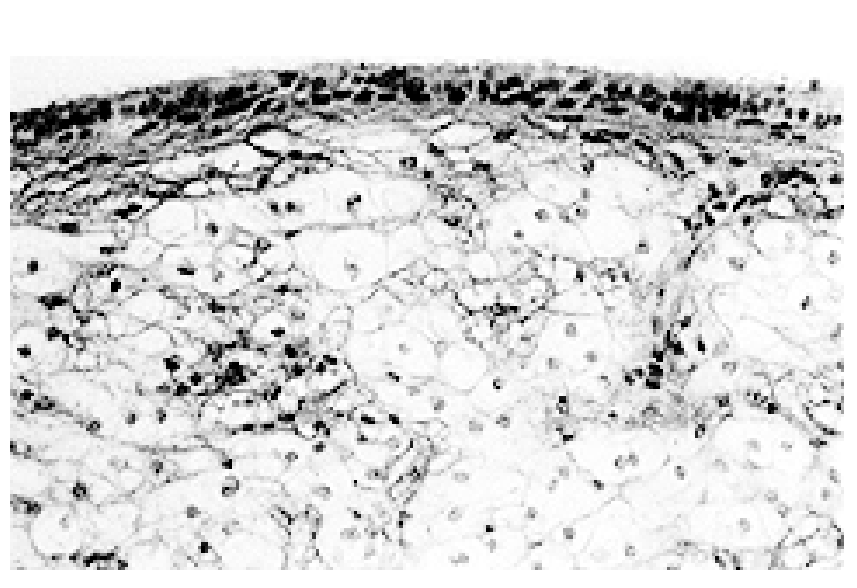

Fig. 2. Case 1. Photomicrograph demonstrating the typical histological appearance of one physaliphorous cell-rich chordoma composed of lobular cell clusters embedded in a mucoid stroma. The tumor invades the submucosa of sphenoid sinus. H \& E, original magnification $\times 160$. no mitotic figures (Fig. 2). Examination of the specimen by using the period-acid-Schiff method demonstrated abundant cytoplasmic glycogen. Fragments of adenohypophysial parenchyma adjacent to chordoma elements appeared to be histologically normal. Immunocytochemical analysis of the chordoma cells showed focal positivity for EMA, S-100 protein, $\alpha 1-F P$, and vimentin. In addition, the cells were immunoreactive for pan-keratin but negative for the HMW keratins 1, 5, 10, and 14 (Fig. 3). Scant immunoreactivity for CEA was also noted, whereas NSE stains were negative. Ultrastructurally, the tumor was composed of large cells containing irregular nuclei with multiple indentations and prominent nucleoli. The latter scattered profiles of rough endoplasmic reticulum, occasional mitochondria, beta particles of glycogen intermediate filaments, and vacuoles. Cytoplasmic vacuoles were smaller than those in the intercellular matrix. Analysis of DNA revealed a diploid histogram.

\section{Case 2}

This 80-year-old woman presented with a 1-month history of right ptosis, which had been followed within days by the occurrence of ipsilateral orbital pain. Her medical history was noncontributory. A CT scan revealed a contrast-enhancing intrasellar mass that was eroding the sell-

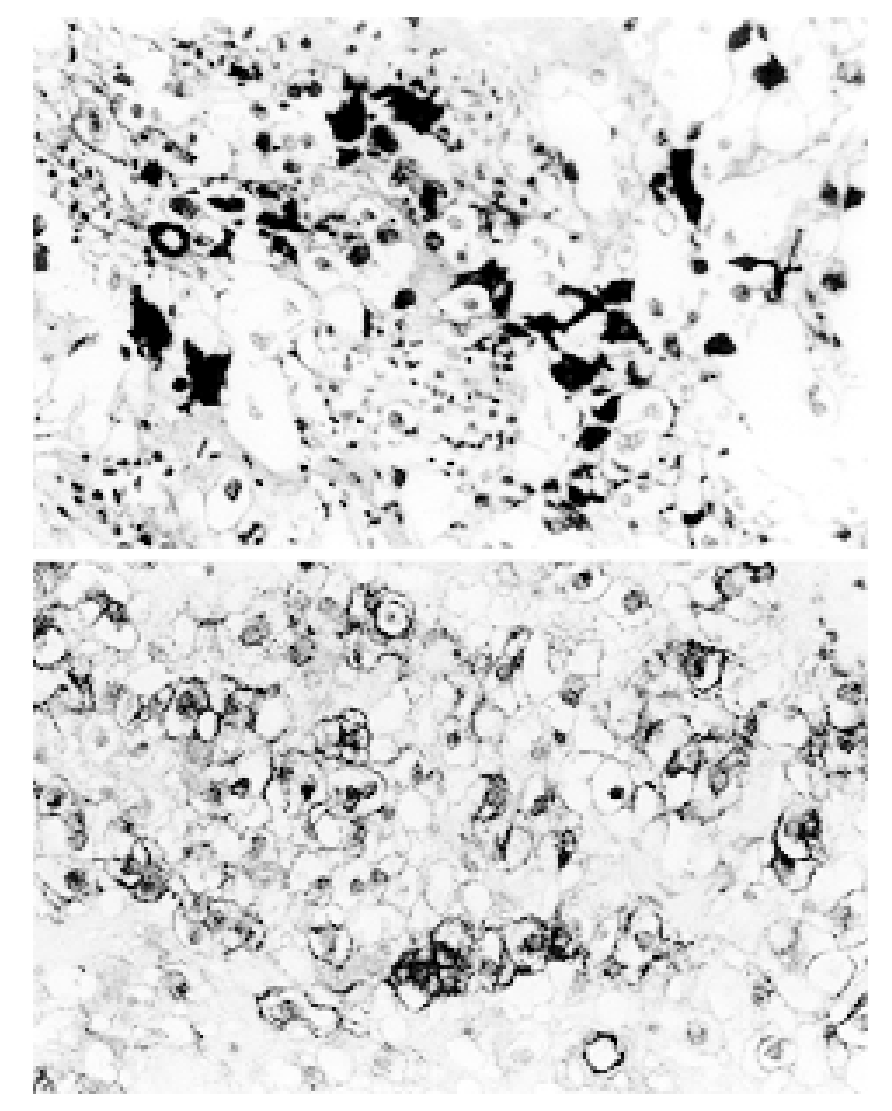

Fig. 3. Case 1. Photomicrographs of physaliphorous cell-rich chordoma showing strong, diffuse cytoplasmic reactivity for cytokeratins (upper) and characteristic membranous staining for EMA (lower). Avid-biotin-peroxide complex, original magnification $\times 160$ 


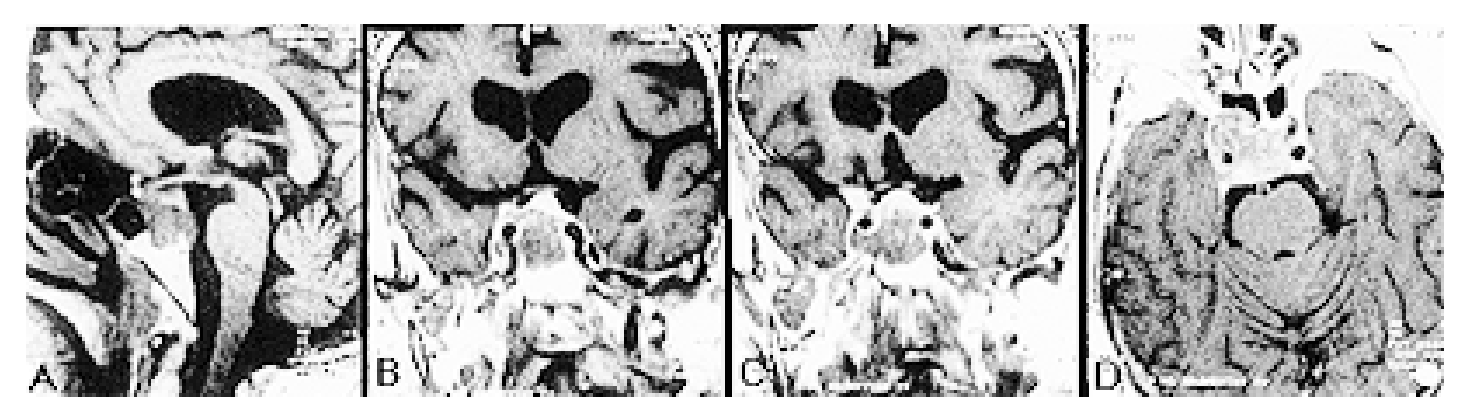

Fig. 4. Case 2. Magnetic resonance imaging studies. Sagittal (A) and coronal (B and C) MR images revealing a large mass occupying the pituitary fossa, elevating the pituitary gland and optic chiasm, and invading the right cavernous sinus. D: Horizontal MR image demonstrating invasion of the right cavernous sinus and the sphenoid sinus, with protrusion into the sphenoid sinus cavity.

ar floor and a small portion of the clivus. In addition, MR imaging demonstrated that the mass measured $2.5 \mathrm{~cm}$ in diameter and that it occupied the pituitary fossa, invaded the right cavernous sinus, and protruded into the sphenoid sinus (Fig. 4). Its upward growth elevated the pituitary gland and the optic chiasm. Moderate tumoral contrast enhancement was noted, mainly at its periphery. Despite a slightly elevated basal prolactin level $(36 \mathrm{ng} / \mathrm{ml}$; normal range $5-20 \mathrm{ng} / \mathrm{ml}$ ) the endocrinological assessment demonstrated normal findings. On opening the dura at transsphenoidal surgery, the tumor was seen to protrude into the sphenoid sinus. The rather hard and moderately hemorrhagic tumor was partially removed.

Pathological Findings. Microscopically, the tumor was composed of lobules of large cells with uniform nuclei, mostly embedded in a chondroid stroma. Small numbers of vacuolated (physaliphorous) cells were arranged in a syncytial manner (Fig. 5). In addition, lobules of tumor cells were occasionally separated by bundles of fibrous tissue. The tumor cells contained abundant glycogen. Immunostains were positive for EMA, S-100 protein, vimentin, and for cytokeratins 5, 8, 18, and 19. The CEA preparations showed only mild focal immunoreactivity.

\section{Case 3}

A 63-year-old woman was referred to the Mayo Clinic for resection of an incidentally discovered sellar mass. While undergoing chemotherapy for local recurrence of a previously resected ovarian carcinoma, she was noted to have developed a right scotoma. Ophthalmological evaluation demonstrated a right-sided pupillary defect, and visual field examination revealed an ipsilateral asymmetric bitemporal hemianopsia. On subsequent radiological evaluation, a large asymmetric intrasellar mass was seen to be eroding the right anterior clinoid artery. A CT scan revealed suprasellar extension on the right side. The sellar floor and clivus appeared normal. Basal serum prolactin levels were elevated at $97.5 \mathrm{ng} / \mathrm{ml}$, whereas follicle-stimulating hormone and luteinizing hormone levels were low at $15.2 \mathrm{mIU} / \mathrm{ml}$ and $3.3 \mathrm{mIU} / \mathrm{ml}$, respectively (normal range $20-138 \mathrm{mIU} / \mathrm{ml}$ and $15-62 \mathrm{mIU} / \mathrm{ml}$, respectively). Both clinical and neuroimaging findings suggested a nonsecreting pituitary adenoma with chiasmal compression (Hardy Grade IIIB). ${ }^{16}$ During transsphenoidal surgery, the sphenoid bone was destroyed, the sinus itself being filled with a multinodular tumor of rubbery consistency. The lesion had greatly expanded the dura. The entire tumor, both intrasellar and intracranial, was removed. The postoperative course was uneventful, with significant improvement of right-sided vision. Four months later, the patient died of the underlining ovarian cancer. No autopsy was performed.

Pathological Findings. On light microscopic examination, the tumor was shown to be composed primarily of physaliphorous cells forming sheets that were separated by broad fibrous bands. Focal hemorrhage and hemosiderin deposits were observed (Fig. 6). One tissue fragment showed bone invasion.

\section{Sources of Supplies and Equipment}

The Elite Vectastain kit (Vector Laboratories Inc., Burlingame, CA) was used in the cytochemical analysis. We obtained the following supplies from Dako A/S (Copenhagen, Denmark): monoclonal (1:1000) EMA, polyclonal $(1: 1000) \mathrm{S}-100$ protein, polyclonal $(1: 2000) \alpha 1$-FP, polyclonal (1:1000) CEA, and monoclonal (1:1000) NSE. The monoclonal $(1: 1500)$ vimentin is manufactured by Sigma Chemical Co. (St. Louis, MO). We acquired the pan-keratin cocktail CK22 from Biomeda (Foster City, CA). The HMW cytokeratins 1, 5, 10, and 14 (monoclonal, clone $34 \beta 12$, prediluted) were purchased from Enzo

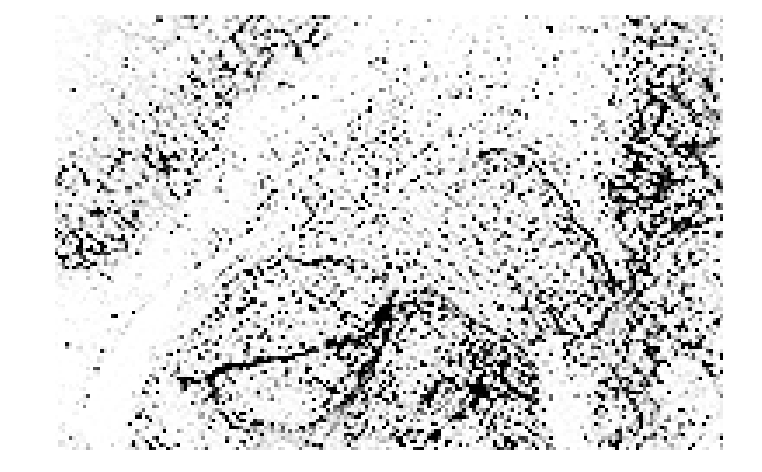

Fig. 5. Case 2. Photomicrograph demonstrating the typical histological appearance of chordoid chordoma composed of lobules of large cells with uniform nuclei, mostly embedded in chondroid stroma. H \& E, original magnification $\times 400$. 


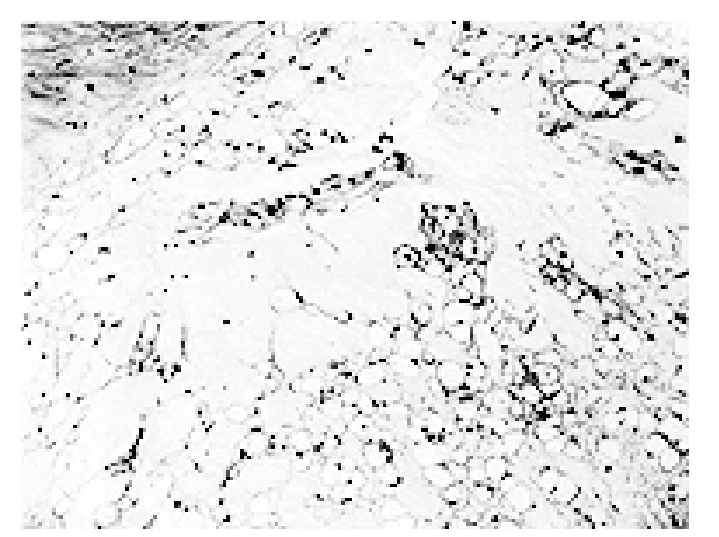

Fig. 6. Case 3. Photomicrograph depicting a physaliphorous cell-rich chordoma composed of large vacuolated cells forming sheets that are separated by broad fibrous bands. H \& E, original magnification $\times 100$.

Diagnostics Inc. (Farmingdale, NY). The cytokeratins 5 and 8 (monoclonal, clone RCK102, prediluted) and the LMW cytokeratins 8, 18, and 19 (monoclonal, clone NC L5D3, prediluted) were acquired from Monosan (Uden, The Netherlands). Serve, Feinbiochemica (Heidelberg, Germany) manufactures the Epon and Araldite.

The image analyzer (CAS 200) is manufactured by CAS Inc. (Elmhurst, IL), and the electron microscope (JEM-100CX2) is produced by JEOL Ltd. (Tokyo, Japan).

\section{DISCUSSION}

The genesis of chordomas has been linked to notochordal rests, which found are embedded in the dorsum sellae in 4 to $5 \%$ of adult autopsies ${ }^{51}$ Despite initial skepticism, ${ }^{39}$ many researchers now believe that such rests appear to represent sites at which sellar chordomas develop. Similarities in immunohistochemical, ultrastructural, and in vitro features between chordoma and notochordal elements provide support for the notochordal theory. ${ }^{6}$ To date, only one case has been reported in which there was an entirely intrasellar chordoma unassociated with sphenoid bone involvement. ${ }^{31}$

The incidence of endocranial chordomas shows a slight male predilection (6:5), ${ }^{50}$ whereas chordomas occurring at other sites exhibit a 2:1 male/female ratio. ${ }^{19}$ The incidence of skull base chordomas is also higher in younger-age patients, often appearing in the second to fifth decades ${ }_{17,19,20}$ Based on anatomical location and clinical features, ${ }^{14}$ chordomas of the skull base can be classified into three categories: 1) sellar chordomas associated with chiasmal compression and hypopituitarism; 2) parasellar tumors characterized by oculomotor nerve palsy, optic tract compression, and hypopituitarism; and 3) tumors involving the clival region and presenting with bilateral sixth cranial nerve paresis and brainstem compression. Accordingly, our three cases are classified as having chordoma defined in the first classification.

As previously stated, chordomas involving the sellar region are uncommon. Including of our three cases, only 21 tumors with a primarily intrasellar component have been reported since 1966 (Table 1)., 2,4,7,9,12,14,22,23,31,32,37,38,46,47 No sex predilection was noted, and patients' ages were within the expected range. Fifteen patients experienced visual deficits $(71.4 \%)$. In nine cases $(43 \%)$ a pituitary adenoma was suspected.

The neuroimaging features of Falconer Type 1 and 2 lesions,${ }^{14}$ particularly when accompanied by endocrinological signs, can easily prompt an erroneous diagnosis of pituitary adenoma. Hyperprolactinemia and hypopituitarism commonly result from compression of the pituitary stalk ("stalk section effect") and of the pituitary. As a result, sellar chordomas may mimic prolactinomas or nonfunctioning pituitary adenomas.

Some authors advocate obtaining a preliminary transsphenoidal biopsy sample to establish a histological dianosis that aids in the design of surgical therapy.,11 Dynamic MR imaging may also contribute to the differentiation of sellar chordoma from meningioma, schwannoma, and metastatic tumor. ${ }^{21}$ Magnetic resonance spectroscopy may provide additional information for the preoperative diagnosis of brain tumors. Based on differences in their metabolic profile, MR spectroscopy may differentiate pituitary adenomas from other sellar-region masses that originate outside the pituitary gland. With regard to sellar chordomas, however, it is of note that the technique failed to diagnose one recently reported patient with chondroid chordoma involving the sellar region and left jungular foramen ${ }^{24}$ In addition to pituitary adenoma, ${ }^{22}$ craniopharyngioma, ${ }^{23}$ and a small number of rare tumors affecting the sellar region, ${ }^{42}$ the differential diagnosis of chordoma also includes cartilaginous tumors of the skull base. ${ }^{34}$ These include primarily chondrosarcoma and cartilage-containing chordomas ("chondroid chordoma"). The latter, long considered a special prognostically favorable variant of chordoma, ${ }^{17}$ was the subject of a recent clinicopathological study, ${ }^{34}$ in which the authors found no inherent difference in the survival of such chordomas as compared with conventional chordoma and chondrosarcoma. Instead, the more favorable prognosis in patients with chondroid chordoma was attributed to their occurrence in younger patients.

Evident in the immunoprofile of chordoma cells is reactivity for LMW cytokeratins 7, 8, 18, and 19 (simple epithelium), as well as HMW 4, 5, and 6 (mucosal epithelia), ${ }^{18,34,40}$ vimentin and EMA. ${ }^{1,5,8,32,33}$ The results of our immunocytochemical analyses are in accordance with these findings. In both Cases 1 and 2 EMA and vimentin were expressed. Examination demonstrated immunopositivity for a panepithelial cytokeratin cocktail in Case 1 and positivity for both LMW and HMW cytokeratins in Case 2. Approximately $50 \%$ of chordomas are S-100-protein immunoreactive. ${ }^{34}$ Inconsistent staining results for CEA have also been reported. ${ }^{5,32,33,40}$ Immunostaining for NSE and $\alpha 1-\mathrm{FP}$ yield positive results in the majority of tumors. ${ }^{1,5,8,32,34}$ Focal immunopositivity for S-100 and CEA was apparent in our two cases tested (Cases 1 and 2). In addition to immunocytochemistry, electron microscopy has significantly contributed to the characterization of chordomas. ${ }^{6,20,34}$

Although total resection of chordomas is the theoretical goal, as in cases of extraosseous chordoma,${ }^{31}$ this is only infrequently achieved. Adjuvant radiotherapy has been recommended to prolong the disease-free survival, but its 


\section{Intrasellar chordomas mimicking pituitary adenoma}

TABLE 1

Cases of chordomas of the sellar region obtained from review of the literature \& present report

\begin{tabular}{|c|c|c|c|c|c|c|c|c|c|}
\hline $\begin{array}{l}\text { Case } \\
\text { No }\end{array}$ & $\begin{array}{l}\text { Authors } \\
\& \text { Year }\end{array}$ & $\begin{array}{l}\text { Age }(y r s) \\
\text { Sex }\end{array}$ & $\begin{array}{l}\text { Symptom } \\
\text { Duration } \\
(\text { mos })\end{array}$ & $\begin{array}{l}\text { Clinical } \\
\text { Findings }\end{array}$ & $\begin{array}{l}\text { Sellar } \\
\text { Relation }\end{array}$ & $\begin{array}{l}\text { Endocrine Signs } \\
\& \text { Possible Diagnosis }\end{array}$ & $\begin{array}{l}\text { No. of } \\
\text { Ops }\end{array}$ & $\begin{array}{l}\text { Radiation } \\
\text { Dose (cGy) }\end{array}$ & $\begin{array}{c}\text { Survival } \\
(\mathrm{mos})\end{array}$ \\
\hline 1 & Belza, 1966 & $53, \mathrm{M}$ & UN & $\begin{array}{l}\text { incomplete lt IIIrd } \\
\text { CN palsy }\end{array}$ & intra- & UN & 2 & 6000 & 20 \\
\hline 2 & $\begin{array}{l}\text { Falconer, et al., } \\
1968\end{array}$ & $51, \mathrm{M}$ & 60 & $\begin{array}{l}\text { chiasmal compres- } \\
\text { sion, rhinorrhea, } \\
\text { meningitis }\end{array}$ & $\begin{array}{l}\text { intra-, supra-, } \\
\quad \& \text { infra- }\end{array}$ & hypopituitarism & 3 & UN & 48 \\
\hline 3 & & $42, \mathrm{~F}$ & 72 & $\begin{array}{l}\text { headaches, tem- } \\
\text { poral hemian- } \\
\text { opsia }\end{array}$ & $\begin{array}{l}\text { intra-, supra-, } \\
\text { \& para- }\end{array}$ & amenorrhea & 1 & 5000 & 50 \\
\hline 4 & & $47, \mathrm{M}$ & 4 & $\begin{array}{l}\text { optic track com- } \\
\text { pression, unilat } \\
\text { IIIrd CN palsy }\end{array}$ & $\begin{array}{l}\text { intra-, supra-, } \\
\quad \& \text { para- }\end{array}$ & pituitary adenoma & 2 & 3500 & 36 \\
\hline 5 & $\begin{array}{l}\text { Steimlé, et al., } \\
1969\end{array}$ & $52, \mathrm{~F}$ & 180 & $\begin{array}{l}\text { migranous head- } \\
\text { aches }\end{array}$ & intra- & $\begin{array}{l}\text { amenorrhea } 13 \text { yrs } \\
\text { ago }\end{array}$ & & $\mathrm{NO}$ & $>18$ \\
\hline 6 & $\begin{array}{l}\text { Chadduck, } \\
1973\end{array}$ & $63, \mathrm{~F}$ & UN & $\begin{array}{l}\text { signs from lt II, } \\
\text { III, IV, V, and } \\
\text { VI CNs }\end{array}$ & $\begin{array}{l}\text { intra-, supra-, } \\
\quad \& \text { infra- }\end{array}$ & pituitary adenoma & UN & UN & 96 \\
\hline 7 & $\begin{array}{l}\text { Mathews \& } \\
\text { Wilson, } 1974\end{array}$ & $41, \mathrm{M}$ & 24 & $\begin{array}{l}\text { rt visual impair- } \\
\text { ment, bitem- } \\
\text { poral hemian- } \\
\text { opsia }\end{array}$ & intra- \& supra- & $\begin{array}{l}\text { hypothyroidism, } \\
\text { acromegaly }\end{array}$ & 2 & UN & UN \\
\hline 8 & $\begin{array}{r}\text { de Cremoux, } \\
\text { et al., } 1980\end{array}$ & $66, \mathrm{M}$ & $1 / 2$ & $\begin{array}{l}\text { disorientation, } \\
\text { mental defects }\end{array}$ & $\begin{array}{l}\text { intra-, supra-, \& } \\
\text { para- }\end{array}$ & UN & 1 & 6000 & UN \\
\hline 9 & & $39, \mathrm{~F}$ & 7 & & $\begin{array}{l}\text { intra-, supra-, \& } \\
\text { para- }\end{array}$ & $\begin{array}{l}\text { amenorrhea, gal- } \\
\text { actorrhea, pro- } \\
\text { lactinoma }\end{array}$ & 1 & UN & UN \\
\hline 10 & $\begin{array}{l}\text { Pluot, et al., } \\
1980\end{array}$ & $48, \mathrm{M}$ & 17 & $\begin{array}{l}\text { It visual impair- } \\
\text { ment, exoph- } \\
\text { thalmos }\end{array}$ & intra- \& supra- & UN & 1 & 6100 & $>84$ \\
\hline 11 & & $53, \mathrm{~F}$ & 60 & $\begin{array}{l}\text { diplopia, lt } \\
\text { visual impair- } \\
\text { ment }\end{array}$ & intra- \& para- & UN & 1 & 5000 & $>11$ \\
\hline 12 & $\begin{array}{l}\text { Tan, et al., } \\
1982\end{array}$ & $26, \mathrm{M}$ & 8 & $\begin{array}{l}\text { It eye pain, } 1 \mathrm{t} \\
\text { temporal blind- } \\
\text { ness }\end{array}$ & intra- \& supra- & $\begin{array}{l}\text { pituitary adenoma } \\
\text { or craniopharyn- } \\
\text { gioma }\end{array}$ & 1 & NO & UN \\
\hline 13 & $\begin{array}{l}\text { Elias \& } \\
\quad \text { Pavers, } 1985\end{array}$ & $34, \mathrm{M}$ & 6 & diplopia & intra- \& para- & increased prolactin & 1 & UN & UN \\
\hline 14 & $\begin{array}{l}\text { Raffel, et al., } \\
1985\end{array}$ & $42, \mathrm{M}$ & 27 & $\begin{array}{l}\text { headaches, visual } \\
\text { loss }\end{array}$ & intra- & UN & 1 & 6000 & $>14$ \\
\hline 15 & $\begin{array}{l}\text { Arnold \& } \\
\quad \text { Hermann, } 1986\end{array}$ & $37, \mathrm{~F}$ & 3 & lt blindness & $\begin{array}{l}\text { intra-, supra-, \& } \\
\text { para- }\end{array}$ & UN & 2 & UN & $>54$ \\
\hline 16 & $\begin{array}{l}\text { Kagawa, et al., } \\
1993\end{array}$ & $67, \mathrm{~F}$ & UN & $\begin{array}{l}\text { visual impair- } \\
\text { ment }\end{array}$ & intra- \& supra- & hypopituitarism & 2 & UN & $>120$ \\
\hline 17 & $\begin{array}{l}\text { Pinzer, et al., } \\
1993\end{array}$ & $58, \mathrm{~F}$ & 12 & $\begin{array}{l}\text { decreased visual } \\
\text { acuity (lt eye) } \\
\text { congenital blind- } \\
\text { ness (rt eye) }\end{array}$ & $\begin{array}{l}\text { intra-, supra-, \& } \\
\text { para- }\end{array}$ & $\begin{array}{l}\text { craniopharyngioma } \\
\text { or pituitary ade- } \\
\text { noma }\end{array}$ & 2 & UN & $>24$ \\
\hline 18 & $\begin{array}{l}\text { Kikuchi \& } \\
\text { Watanabe, } 1994\end{array}$ & $56, \mathrm{M}$ & 3 & $\begin{array}{l}\text { bilateral visual } \\
\text { impairment }\end{array}$ & intra- \& supra- & $\begin{array}{l}\text { increased prolactin, } \\
\text { craniopharyn- } \\
\text { gioma }\end{array}$ & 1 & UN & UN \\
\hline 19 & present cases & $61, \mathrm{M}$ & 3 & $\begin{array}{l}\text { diplopia, bilateral } \\
\text { visual impair- } \\
\text { ment, headaches }\end{array}$ & $\begin{array}{l}\text { intra-, supra-, \& } \\
\text { para- }\end{array}$ & $\begin{array}{l}\text { nonfunctioning } \\
\text { pituitary adenoma }\end{array}$ & 1 & 6000 & $>48$ \\
\hline 20 & & $80, \mathrm{~F}$ & 1 & rt upper lid ptosis & intra- \& para- & $\begin{array}{l}\text { nonfunctioning } \\
\text { pituitary adenoma }\end{array}$ & 1 & UN & $>15$ \\
\hline 21 & & $63, \mathrm{~F}$ & UN & rt eye scotoma & $\begin{array}{l}\text { intra-, supra-, \& } \\
\text { para- }\end{array}$ & $\begin{array}{l}\text { increased prolactin, } \\
\text { nonfunctioning } \\
\text { pituitary adenoma }\end{array}$ & 1 & NO & UN \\
\hline
\end{tabular}

$* \mathrm{CN}=$ cranial nerve; $\mathrm{NO}=$ no radiation; $\mathrm{UN}=$ unknown.

effect on prolonging overall survival has not been established..$^{15}$ Transsphenoidal surgery followed by radiotherapy is the generally accepted therapy., ${ }^{2,15,17,41}$ The develop- ment of a postirradiation sarcoma is a rare but serious complication ${ }^{20}$ that should be distinguished from sarcomatous transformation of chordoma. ${ }^{49}$ 
In terms of the surgery, the goal of initial management of sellar chordomas is a gross-total resection..$^{26,29}$ Because of the distinct tendency of chordomas to invade surrounding bone, it is true that total removal is generally not possible. Specifically when extensive skull base procedures and large scale resections are performed, minute residua that have permeated bone are often left behind at the resection margins. In addition, chordomas also have the ability to invade and perforate nearby dura. A variety of strategies have been developed to achieve maximum tumor removal, including bifrontal, transsphenoidal, transpalatal, and transmandibular approaches. ${ }^{27,30}$ In most cases, a transsphenoidal approach permits very satisfactory resection of chordomas primarily involving the sella, and it offers the surgeon an opportunity to decompress the suprasellar compartment and optic chiasm, as well as cavernous sinus in which nerves subserving ocular movement may be affected. The transsphenoidal approach also permits one to treat midline tumor involvement of the clivus and of the clival dura. However, the surgeon should consider the limitations of the transsphenoidal approach, particularly when manipulating very hard tumors.

Because the majority of chordoma resections are, by nature incomplete, adjunctive therapy is usually recommended. In our review of pediatric chordomas, it was interesting to note that all long-term survivors had undergone radiotherapy. ${ }^{52}$ Conventional fractionated radiotherapy has been the most commonly used; however, stereotactically delivered "radiosurgery," either linear accelerator or gamma knife, has recently become vogue. ${ }^{3,13,25,35}$ In the future, these modalities may play a significant role in the treatment of patients with chordomas; at present, it is too early to assess their efficacy. The Harvard group, which administered fractionated stereotactic proton-beam radiosurgery, has treated a large number of patients harboring chordomas and chondrochordomas of the skull base, ${ }^{28}$ and their results have been outstanding. Their technique clearly permits the delivery of an effective radiation dose while protecting vital structures. Once a chordoma has been successfully resected, one ordinarily recommends annual follow up in which the patient undergoes high-quality imaging studies to assess for tumor recurrence.

The malignant behavior of skull base chordomas is primarily a function of their location, tendency to osseous permeation, and high rate of recurrence, and not their capacity for metastasis. ${ }^{17,38}$ The metastatic potential of chordomas cannot be estimated by histological examination, except in cases in which the lesion exhibits a high-grade, spindle cell sarcomatous component. ${ }^{19,49}$ In recent clinicopathological studies the authors have claimed that longer survival times are demonstrated in patients younger than 40 years of age ${ }^{15,34}$ as well as in those presenting with diplopia. ${ }^{15}$ The overall survival rate in the study conducted by Forsyth, et al., ${ }^{15}$ was estimated to be $51 \%$ and $35 \%$ at 10 years and 20 years, respectively. With regard to DNA analysis of chordomas, analysis of recent findings has shown a statistical trend in the relationship of diploidy and a favorable prognosis. ${ }^{44,45}$ The long recurrence-free period observed in one patient (Case 19, Table 1) in our series may be related to the diploid DNA histogram of the tumor.

In summary, sellar chordomas are rare. Their occasional favorable prognosis no doubt relates to the limited extent of disease and the aggressiveness of the surgical resection. The effect of radiation therapy on disease-free and overall survival rates remains unsettled.

\section{References}

1. Abenoza P, Sibley RK: Chordoma: an immunohistologic study. Hum Pathol 17:744-747, 1986

2. Arnold H, Herrmann HD: Skull base chordoma with cavernous sinus involvement. Partial or radical tumor-removal? Acta Neurochir 83:31-37, 1986

3. Austin-Seymour M, Munzenrider J, Goiten M, et al: Fractionated proton radiation therapy of chordoma and low-grade chondrosarcoma at the base of the skull. J Neurosurg 70:13-17, 1989

4. Belza J: Double midline intracranical tumours of vestigial origin: contiguous intrasellar chordoma and suprasellar craniopharyngioma. Case report. J Neurosurg 25:199-204, 1966

5. Bouropoulou V, Kontogeorgos G, Papamichales G, et al: Differential diagnosis of chordoma immunohistological aspects. Arch Anat Cytol Pathol 35:35-40, 1987

6. Burger PC, Scheithauer BW, Vogel SF: Surgical Pathology of the Nervous System and its Coverings, ed 3. New York: Churchill Livingstone, 1991, pp 503-536

7. Chadduck WM: Unusual lesions involving the sella turcica. South Med J 66:948-955, 1973

8. Coindre JM, Rivel J, Trogiani M, et al: Immunohistological study in chordomas. J Pathol 150:61-63, 1986

9. de Cremoux P, Turpin U, Hamon P, et al: Les chordomes intrasellaires. Principaux aspects cliniques, biologiques, radiologiques, évolutifs et histologiques: a propos de deux observations. Sem Hôp 56:1769-1773, 1980

10. Derome P, Akerman M, Anquez L, et al: Les tumeurs sphénoethmoïdales. Possibilités d' exérèse et de reparation chirurgicales. Neurochirurgie 18 (Suppl 1):1-164, 1972

11. Derome P, Guiot G: Surgical approaches to the sphenoidal and clival areas. Adv Tech Stand Neurosurg 6:101-136, 1979

12. Elias Z, Powers SK: Intrasellar chordoma and hyperprolactinemia. Surg Neurol 23:173-176, 1985

13. Fagundes MA, Hug EB, Liebsch NJ, et al: Radiation therapy for chordoma of the base of the skull and cervical spine: patterns of failure and outcome after relapse. Int J Radiat Oncol Biol Phys 33:579-584, 1995

14. Falconer MA, Bailey IC, Duchen LW: Surgical treatment of chordoma and chondroma of the skull base. J Neurosurg 29: 261-275, 1968

15. Forsyth PA, Cascino TL, Shaw EG, et al: Intracranial chordomas: a clinicopathological and prognostic study of 51 cases. $\mathbf{J}$ Neurosurg 78:741-747, 1993

16. Hardy J: Transsphenoidal surgery of hypersecreting pituitary tumors, in Kohler PO, Ross GT (eds): Diagnosis and Treatment of Pituitary Tumors. International Congress Series, Vol 303. Amsterdam: Exerpta Medica, 1973, pp 179-198

17. Heffelfinger MJ, Dahlin DC, MacCarty CS, et al: Chordomas and cartilaginous tumors at the skull base. Cancer 32:410-420, 1973

18. Heikinheimo K, Persson S, Kindblom LG, et al: Expression of different cytokeratin subclasses in human chordoma. J Pathol 164:145-150, 1991

19. Higinbotham NL, Phillips RF, Farr HW, et al: Chordoma. Thirty-five-year study at Memorial Hospital. Cancer 20: 1841-1850, 1967

20. Huvos AG: Bone Tumors. Diagnosis, Treatment, and Prognosis, ed 2. Philadelphia: WB Saunders Co, 1991, pp 599-616

21. Ikushima I, Korogi Y, Hirai T, et al: Chordomas of the skull base: dynamic MRI. J Comput Assist Tomogr 20:547-550, 1996 
22. Kagawa T, Takamura M, Moritake K, et al: A case of sellar chordoma mimicking a non-functioning pituitary adenoma with survival of more than 10 years. Noshuyo Byori 10:103-106, 1993

23. Kikuchi K, Watanabe K: Huge sellar chordoma: CT demonstration. Comput Med Imaging Graph 18:385-390, 1994

24. Kinoshita Y, Yokota A: Absolute concentrations of metabolites in human brain tumors using in vitro proton magnetic resonance spectroscopy. NMR Biomed 10:2-12, 1997

25. Kondziolka D, Lunsford LD, Flickinger JC: The role of radiosurgery in the management of chordoma and chondrosarcoma of the cranial base. Neurosurgery 29:38-46, 1991

26. Lalwani AK, Kaplan MJ, Gutin PH: The transsphenoethmoid approach of the sphenoid sinus and clivus. Neurosurgery 31: 1008-1014, 1992

27. Laws ER Jr: Clivus chordomas, in Sekhar LN, Janecka IP (eds): Surgery of Cranial Base Tumors. New York: Raven Press, 1993, pp 679-685

28. Laws ER Jr: Cranial chordomas, in Wilkins RH, Rengachary SS (eds): Neurosurgery. New York: Mc Graw-Hill, 1985, Vol 1, pp 927-930

29. Laws ER Jr: Transsphenoidal surgery for tumors of the clivus. Otolaryngol Head Neck Surg 92:100-101, 1984

30. Maira G, Pallini R, Anile C, et al: Surgical treatment of clival chordomas: the transsphenoidal approach revisited. J Neurosurg 85:784-792, 1996

31. Mathews W, Wilson CB: Ectopic intrasellar chordoma. Case report. J Neurosurg 40:260-263, 1974

32. Meis JM, Giraldo AA: Chordoma. An immunohistochemical study of 20 cases. Arch Pathol Lab Med 112:553-556, 1988

33. Miettinen M: Chordoma. Antibodies to epithelial membrane antigen and carcinoembryonic antigen in differential diagnosis. Arch Pathol Lab Med 108:891-892, 1984

34. Mitchell A, Scheithauer BW, Unni KK, et al: Chordoma and chondroid neoplasms of the spheno-occiput. An immunohistochemical study of 41 cases wih prognostic and nosologic implications. Cancer 72:2943-2949, 1993

35. Muthukumar N, Kondziolka D, Lunsford LD, Flickinger JC: Stereotactic radiosurgery for chordoma and chondrosarcoma: further experiences. Int J Radiat Oncol Biol Phys 41: 387-392, 1998

36. Pinzer T, Tellkamp H, Schaps P: [Intracranial chordoma. Case report of a destructively growing chondroid chordoma in the area of the sella turcica.] Zentralbl Neurochir 54:133-138, 1993 (Ger)

37. Pluot M, Bernard MH, Rousseaux P, et al: Deux observations de chordome de la selle urcique. Etude ultrastructurale et histochimique. Arch Anat Cytol Pathol 28:230-236, 1980

38. Raffel C, Wright DC, Gutin PH, et al: Cranial chordomas: clinical presentation and results of operative and radiation therapy in twenty-six patients. Neurosurgery 17:703-710, 1985

39. Rushell DS, Rubinstein LJ: Pathology of Tumours of the Nervous System, ed 2. London: Edward Arnold, 1971

40. Rutherfoord GS, Davies AG: Chordomas-ultrastructure and immunocytochemistry: a report based on the examination of six cases. Histopathology 11:775-787, 1987

41. Rich TA, Schiller A, Suit HD, et al: Clinical and pathologic review of 48 cases of chordoma. Cancer 56:182-187, 1985

42. Sautner D, Saeger W, Lüdecke DK: Tumors of the sellar region mimicking pituitary adenomas. Exp Clin Endocrinol 101: 283-289, 1993

43. Scheithauer BW: Pathology of the pituitary and sellar region: exclusive of pituitary adenoma, in Sommers SC, Rosen PP (eds): Pathology Annual. Norwalk, CT: Appleton-CenturyCroft, 1985, pp 67-155

44. Schoedel KE, Martinez AJ, Mahoney TM, et al: Chordomas: pathological features; ploidy and silver nucleolar organizing analysis. A study of 36 cases. J Neurooncol 89:139-143, 1995

45. Spaar FW, Spaar U, Markakis E: DNA in chordomas of the clivus Blumenbachi. Neurosurg Rev 13:219-229, 1990

46. Steimlé R, Coudry H, Pageaut G, et al: Chondrome sellaire voie d' abord trans-sphenoïdale. Acta Neurochir 20:237-247, 1969

47. Sundaresan N, Huvos AG, Krol G, et al: Surgical treatment of spinal chordomas. Arch Surg 122:1479-1482, 1987

48. Tan WS, Spigos D, Khine N: Chordoma of the sellar region. J Comput Assist Tomogr 6:154-158, 1982

49. Tomlinson FH, Scheithauer BW, Forsythe PA, et al: Sarcomatous transformation in cranial chordoma. Neurosurgery 31:13-18, 1992

50. Watkins L, Khudados ES, Kaleoglu M, et al: Skull base chordomas: a review of 38 patients, 1958-88. Br J Neurosurg 7: 241-248, 1993

51. Willis RA: Pathology of Tumors, ed 3. London: Butterworths, 1960, pp 926-1002

52. Wold LE, Laws ER Jr: Cranial chordomas in children and young adults. J Neurosurg 59:1043-1047, 1983

Manuscript received October 14, 1999.

Accepted in final form January 5, 2000

Address reprint requests to: George Kontogeorgos, M.D., Department of Pathology, General Hospital of Athens, 154 Messogion Avenue, Athens, Greece. email: gkonto@cc.uoa.gr. 